\title{
Biliary and pancreatic secretory component of the migrating myoelectric complex in the pig. Effect on intraduodenal $\mathrm{pH}$
}

\author{
J. ABELLO, J. P. LAPLACE, T. CORRING
}

With the technical assistance of Sylvette GOUGIS, Georgette BRACHET and F. COINTEPAS

Laboratoire de Physiologie de la Nutrition, I.N.R.A., 78350 Jouy-en-Josas, France.

Summary. The aim of the present study in the pig was to describe the biliary and pancreatic secretory component of the migrating myoelectric complex (MMC) during the interdigestive period and after feeding, and to examine the effects of the extracorporal diversion of biliary or pancreatic secretions on the MMC and on the cyclical variation of intraduodenal $\mathrm{pH}$.

In a first trial six pigs $(50.6 \pm 1.6 \mathrm{~kg})$ were fitted with a permanent catheter in the common bile duct ( 3 pigs) or in the pancreatic duct ( 3 pigs) to control the flow of these secretions. They also had a duodenal catheter to return the secretions, and antral and duodenal electrodes for simultaneous recording of motility in fasting conditions. In a second trial ten pigs $(50.8 \pm 1.5 \mathrm{~kg}$ ) underwent a similar surgical preparation (5 bile duct and 5 pancreatic duct fistulations). They had, in addition, a duodenal T-shaped cannula ( $19 \mathrm{~cm}$ distal to the pylorus) allowing continuous intraluminal $\mathrm{pH}$ recording parallel to the motility recording. Experiments included 4 situations: secretions returned under fed or fasted conditions; by-passed secretions in fed or fasted pigs.

The flow of bile and pancreatic juice was very high during irregular spiking activity phases (ISA), peaking at the beginning of regular spiking activity phases (RSA); it was minimal during quiescent phases. The duration of the duodenal MMC and of its 3 constitutive phases was not modified by total extracorporal diversion of bile or pancreatic secretion either in the fed or fasted state. During the interdigestive period the $\mathrm{pH}$ was significantly reduced under bile diversion (quiescence : 6.17 vs 7.15 ; ISA : 4.91 vs 5.94 ; RSA : 5.40 vs 6.52 ) as well as under pancreatic juice diversion (quiescence : 5.56 vs 7.18 ; ISA : 4.21 vs 5.97 ; RSA : 5.14 vs 6.72 ). In fed pigs only bile diversion resulted in a small acidification during the postprandial pattern (5.07 vs 5.44) and the consecutive MMC cycles (quiescence : 5.81 vs 6.61 ; ISA : 4.66 vs 4.92 ; RSA : 5.11 vs 5.78). Nevertheless the periodicity of $\mathrm{pH}$ variation along the $\mathrm{MMC}$ cycle was unaffected in bile or pancreatic juice-deprived animals.

It is concluded that a true biliary and pancreatic secretory component of MMC exists in the pig, and that these 2 secretions strongly contribute to the neutralization of the duodenal contents. However, the major determinant of the cyclical variation of the intraduodenal $\mathrm{pH}$ appears to be the periodicity of the acid gastric outflow.

\section{Introduction.}

Since the first observation of Szurszewski (1969) in fasting dogs, it has been well established in a great number of animal species (Wingate, 1981 ; Laplace, 
1984) that during the interdigestive state the small intestine exhibits a characteristic pattern of motor activity called the migrating myoelectric complex or the migrating motor complex (MMC). Parallel to these motor events, marked intraduodenal alkalinization has been observed in man (Vantrappen, Peeters and Janssens, 1979). In the pig, cyclical variations of intraduodenal $\mathrm{pH}$ were described by Buéno and Fioramonti (1982) who imputed them exclusively to the fact that the flow of acid gastric digesta alternates with the cessation of gastric output at the onset of each duodenal regular spiking activity phase. However, the experimental conditions of these authors do not allow one to speculate on the possible role of biliary and pancreatic secretions which have been reported to be important in the regulation of intraduodenal $\mathrm{pH}$ and in the neutralization of gastric chyme in fasting pigs (Abello, Corring and Laplace, 1987).

In the gastroduodenal area, chronological coincidence of the MMC cycle with periodic fluctuation of gastric, pancreatic, and biliary secretions, has been described in humans (Vantrappen, Peeters and Janssens, 1979 ; Lux et al., 1980 ; Peeters, Vantrappen and Janssens, 1980) and in fasting dogs (Dimagno et al., 1979 ; Keane et al., 1980). This so-called secretory component of the MMC consists of a cyclic variation of gastric, biliary and pancreatic secretions estimated by the levels of acid and pepsin in the gastric contents or by those of bicarbonate, amylase and bile acids in the duodenal contents. These secretions prove to be maximal at the end of phase II of the MMC (irregular spiking activity, or ISA) and/or at the beginning of phase III (regular spiking activity, or RSA), and might explain the alkalinization of the duodenum during this period.

The purpose of this study was to demonstrate the existence of a biliary and pancreatic secretory component of the MMC in fasting pigs, and to examine the effect of extracorporal diversion of biliary or pancreatic secretions on the MMC and on the cyclical variation of intraduodenal $\mathrm{pH}$.

\section{Material and methods.}

1. Determination of biliary and pancreatic flow rates and characteristics of the $M M C$.

Six castrated male pigs of the Large White breed weighing initially $50.6 \pm 1.6 \mathrm{~kg}$ were used. Under general anaesthesia they were fitted with permanent catheters diverting flow from the common bile duct ( 3 pigs) according to Corring, Juste and Jimenez (1983) or the pancreatic duct (3 pigs) according to Corring, Aumaitre and Rérat (1972). In both cases, the animals were also fitted with a permanent duodenal catheter implanted close to the natural orifice of the fistulated duct to allow diverted secretions to be returned to the duodenum. For recording the motility by chronic electromyography (Laplace, 1983), they were all provided with groups of 3 stainless steel intraparietal electrodes (Laplace, 1972) on the gastric antrum ( 2 and $5 \mathrm{~cm}$ from the pylorus) and on the duodenum $(7,12$ and $20 \mathrm{~cm}$ distal to the pylorus), so that the best bipolar derivation for each location could be selected. 
The day after the operation, the diverted biliary or pancreatic secretions were permanently and automatically returned to the animal at a rhythm corresponding to that of spontaneous secretion (Juste, Corring and Le Coz, 1983a). All animals were allowed to recover after the operation for 8 days. They were accustomed to receive a standard growing diet ( $16 \%$ protein), offered in two meals at 9.00 and $17.00 \mathrm{~h}(800 \mathrm{~g}$ flour diluted in $1600 \mathrm{ml}$ water). Experiments were performed in fasted animals (last meal given $16 \mathrm{~h}$ prior to the recording period) and secretions were returned to the duodenum in all animals. The biliary or pancreatic flow rates and the MMC pattern were recorded simultaneously over $8-h$ periods ( 9.00 to $17.00 \mathrm{~h}$ ). Six recordings were carried out on each pig.

\section{Effect of the diversion of biliary or pancreatic secretions on intraduodenal $\mathrm{pH}$ and the $M M C$.}

Ten Large White pigs weighing initially $50.8 \pm 1.5 \mathrm{~kg}$ were each surgically fitted either with a fistula of the common bile duct or of the pancreatic duct for the extracorporal diversion of secretions, as well as with a permanent duodenal catheter for controlled return of the diverted secretions under the same conditions as those of the first experiment. They were also fitted with a $\mathrm{T}$-shaped cannula for measuring the intraluminal $\mathrm{pH}$ within the duodenum, $19 \mathrm{~cm}$ distal to the pylorus. Four groups of 3 stainless steel electrodes were implanted into the duodenal wall (7, 12, 23 and $28 \mathrm{~cm}$ distal to the pylorus), allowing bipolar derivation of electromyograms (EMG).

After a postoperative recovery of 1 week, the EMG and $\mathrm{pH}$ were simultaneously recorded over 8 -h periods $(9.00$ to $17.00 \mathrm{~h})$. The experiment was designed to test four situations, so that each pig was its own control within the whole bile (5 pigs) or pancreatic (5 pigs) series. Recording sessions were first performed under permanent normal restitution, alternating over 4 consecutive days the fed (test meal at $9.00 \mathrm{~h}$ ) and fasted conditions (last meal given $16 \mathrm{~h}$ prior to recording); then after 3 days without experimentation, a similar schedule was used during permanent diversion of the secretion, i.e. 2 sessions under fed conditions alternating with 2 sessions under fasted conditions. The effects of diverting the secretions were tested by a two-way analysis of variance in each of the four situations.

\section{Mode of recording and expression of results.}

All recordings were made using a pen recorder (Dynograph R.M., Beckman) at a chart speed of $6 \mathrm{~cm} \cdot \mathrm{min}^{-1}$. Electrodes were connected through the front pannel of the recorder to an input coupler with an RC circuit using a short time constant $(0.03 \mathrm{sec})$, allowing the continuous recording of EMG. The outflow of bile or of pancreatic secretion was permanently measured by drop counting using a photoelectric cell (Laplace, 1976b). The signal of the drop counter was transmitted via a relay (HP 2-SF, Bamo mesures) to an event marker. A miniature 
glass electrode (Ingold, model 440), connected to a pHmeter (Zeromatic SS3, Beckman) coupled with the recorder, allowed continuous recording of $\mathrm{pH}$ by $\mathrm{DC}$ amplification.

The duodenal MMC was identified and subdivided into quiescent phase (I), ISA phase (II) and RSA phase (III) according to criteria defined by Code and Marlett (1975). The ISA phase was subdivided into two equal periods called Ila and $\mathrm{IIb}$. The biliary or pancreatic flow rate was measured in the first experiment by quantifying the number of drops per min. Mean values were given for each defined period of the MMC. The characteristics of the MMC under the various conditions were systematically studied in the second experiment only. The $\mathrm{pH}$ values were recorded each min during the MMC pattern.

\section{Results.}

1. MMC-related fluctuations of biliary and pancreatic flow rates.

Continuous recording of the instantaneous flow rate (drop by drop) of biliary and pancreatic secretions evidenced periodic fluctuations in close connection with the cycle of duodenal MMC. The bile secretion (fig. 1) was always minimal

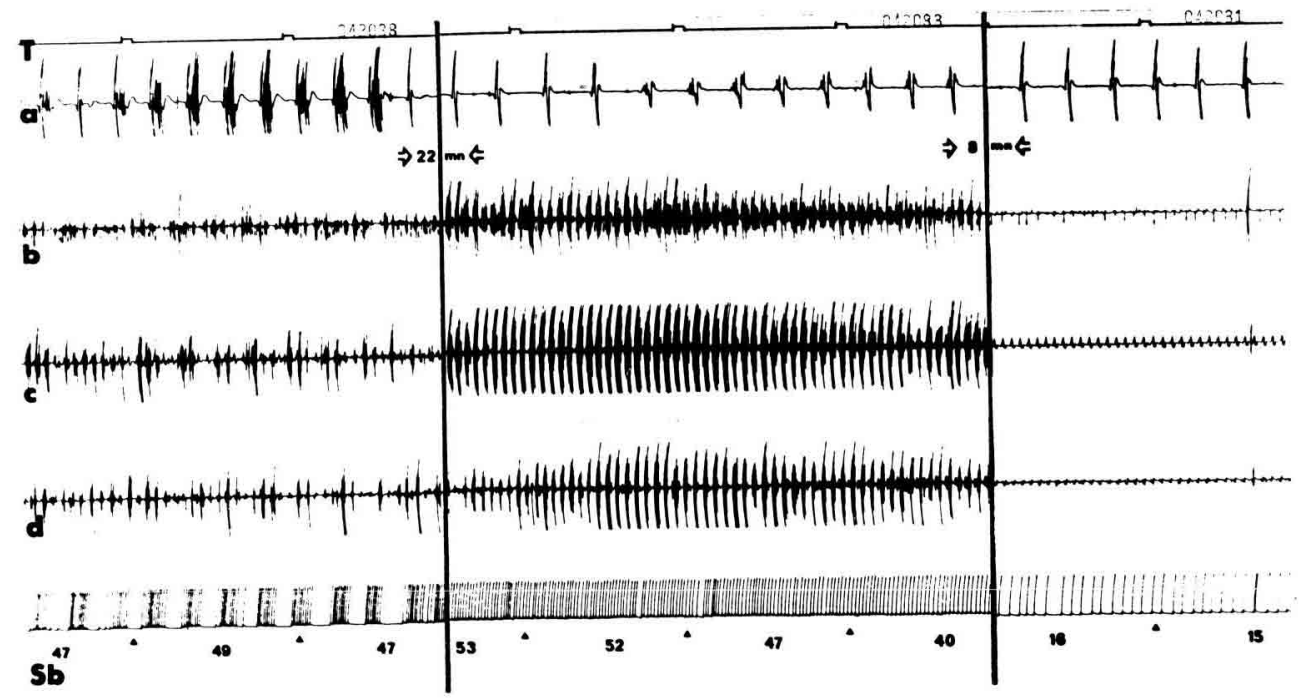

FIG. 1. -- Variation in instantaneous bile flow rate ( $\mathrm{Sb}$ ) shown with myoelectric activity of the gastric antrum (a) and proximal duodenum (b, c, d). The figures indicate the total number of bile drops per $\min (T=$ time basis, $1 \mathrm{~min}$ ). Time intervals between ISA and RSA sequences, and between RSA and quiescence sequences, are indicated between the arrows. 
with values ranging from 1 to 20 drops per min during the quiescent phases. After the start of the ISA phase, the bile flow immediately increased, the surge of bile drops then occurring rhythmically (around four series of drops per min). The flow rate went on increasing to reach a maximum generally observed during the first min of the subsequent RSA phase. At that moment the bile flow rate reached a two or three-fold higher value than the basal one to which it rapidly returned during the early quiescent phase.

As regards pancreatic secretion (fig. 2), the very low basal level (about 3 drops per $\mathrm{min}$ ) was also recorded during the quiescent phase. It increased markedly in the ISA phase and reached a maximum flow rate $(47.5 \pm 2.9$ drops per $\min$ ) at the onset of the RSA phase. During the following min, and before the end of the RSA phase, pancreatic flow declined to the basal value. Despite large between-pig differences in the amplitude of variation of drop counts along the MMC cycle, a similar pattern was observed in all fasted pigs (fig. 3). Within each animal, the difference between the mean values of biliary and pancreatic flow rates, calculated for each phase of the $M M C$, were always significant from one phase to another.
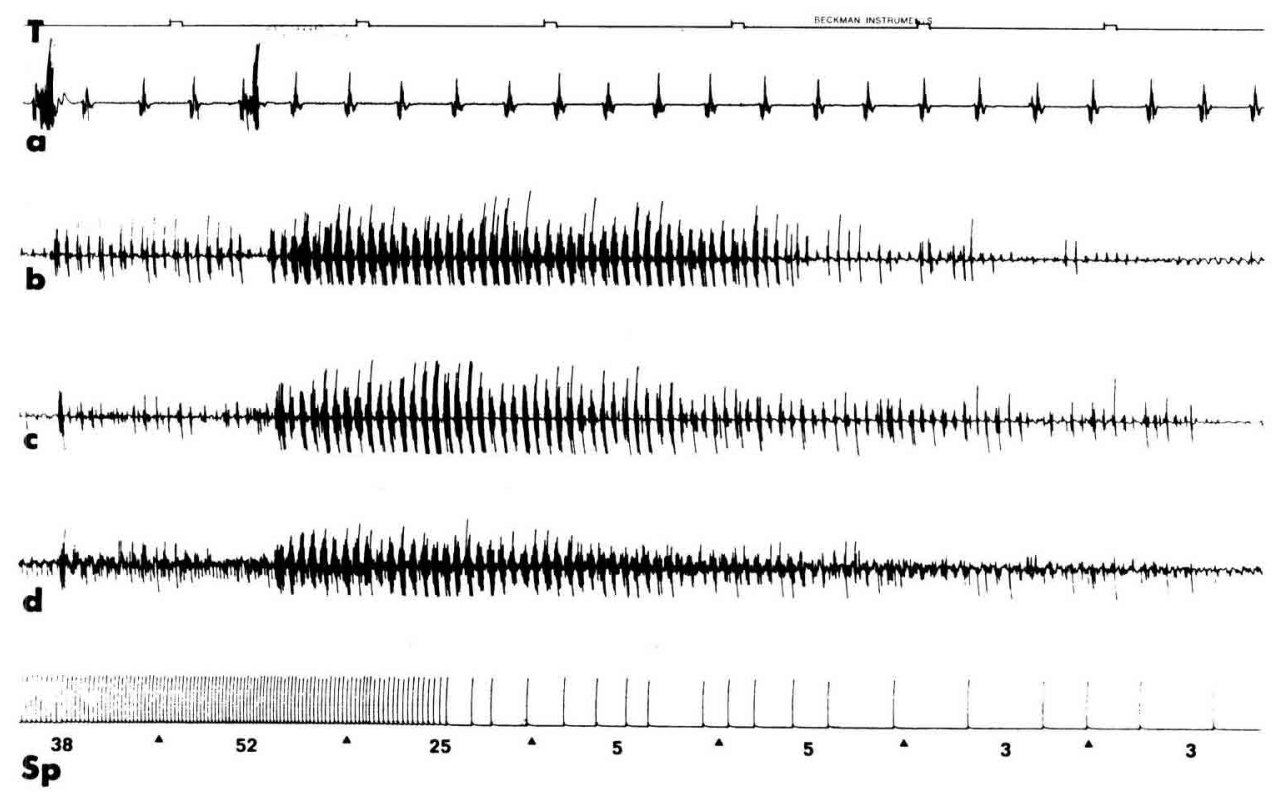

FIG. 2. - Variation in instantaneous pancreatic flow rate ( $\mathrm{Sp}$ ) shown with myoelectric activity of the gastric antrum (a) and proximal duodenum (b, $c, d)$. The figures indicate the total number of drops of pancreatic secretion per $\min (T=$ time basis, 1 min). 

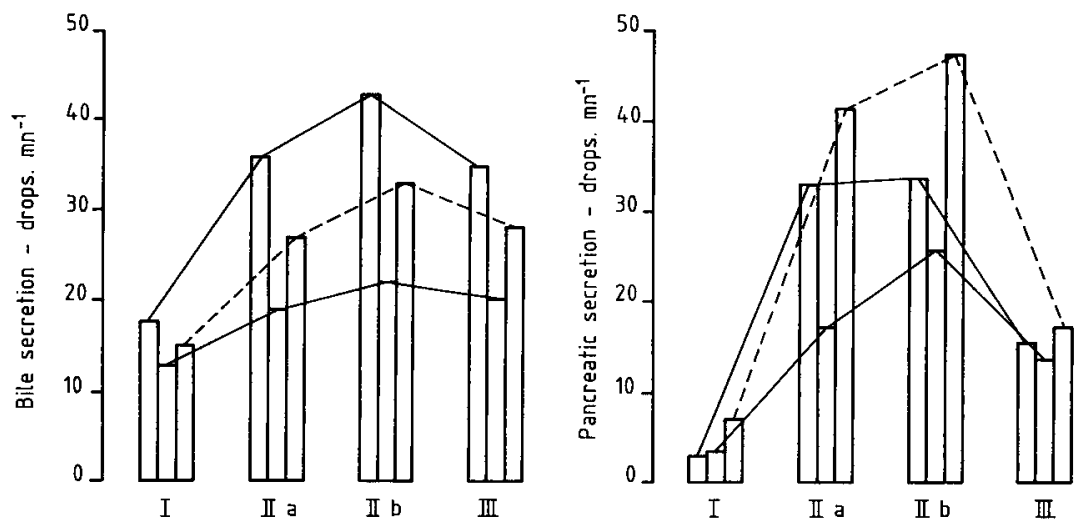

FIG. 3. - Mean values of instantaneous flow rate of biliary and pancreatic secretions calculated for each MMC phase, i.e. quiescent phase (I), ISA (II), RSA (III). The 3 overlapped columns correspond to separately calculated means for the 3 pigs fitted with a biliary or pancreatic fistula. $\mathrm{IIa}$ and IIb correspond to respectively the first and the second half of the ISA phase.

\section{Characteristics of the MMC in pigs fitted with a biliary or pancreatic fistula.}

The mean duration of the MMC and its constitutive phases in pigs whose biliary and pancreatic secretions were returned to or diverted from the duodenum is shown in table 1 . In all pigs there was a relative shortening of the quiescent phase in fed $v s$ fasted conditions. When biliary or pancreatic secretions were diverted from the duodenum of fasted pigs, the quiescent and RSA phases were significantly shortened. When the pigs were fed there was a further significant shortening of the RSA phase in the bile fistula animals only. The duration of the postprandial pattern was not significantly decreased by bile diversion $(75.4 \pm 9.6$ vs $98.6 \pm 8.8 \mathrm{~min})$ nor by pancreatic diversion $(96.0 \pm 13.6$ vs $114.9 \pm 9.0 \mathrm{~min})$.

\section{3. $M M C$ related fluctuations of intraduodenal $\mathrm{pH}$.}

The intraduodenal $\mathrm{pH}$ underwent various types of fluctuations. Very short oscillations whose amplitude could reach $4 \mathrm{pH}$ units within a few seconds (fig. 4), depending on the size and acidity of the gastric outflow, occurred randomly throughout the ISA phase of the MMC. Another kind of $\mathrm{pH}$ variation always coincided with the onset of the RSA phase and subsequent quiescent phase ; it was a relative alkalinization of the duodenum which started during the RSA phase, and then remained stable during late RSA phase and throughout the whole quiescent phase (fig. 5). The resulting $\mathrm{pH}$ plateau, close to neutrality, generally disappeared abruptly at the onset of the subsequent ISA phase.

The periodic recurrence of this alkalinization always coincided with the appearance of the RSA of the duodenal MMC (fig. 6). This cyclically recurring event was observed in both biliary and pancreatic fistula animals under fasted and 
TABLE 1

Mean duration ( $\min \pm$ s.e.m.) of the myoe/ectric migrating complexes (M.M.C.) and their main phases in the two groups of pigs, depending on the experimental conditions.

Five bile duct fistulated pigs

\begin{tabular}{|c|c|c|c|c|c|}
\hline $\begin{array}{l}\text { Feeding } \\
\text { conditions }\end{array}$ & $\begin{array}{l}\text { Bile } \\
\text { secretion }\end{array}$ & $\begin{array}{l}\text { Whole } \\
\text { M.M.C. }\end{array}$ & $\stackrel{1}{\text { Quiescence }}$ & $\stackrel{\text { II }}{\text { I.S.A. }}$ & $\stackrel{\text { III }}{\text { R.S.A. }}$ \\
\hline \multirow{2}{*}{ Fasted } & Returned & $\begin{array}{c}55.4 \pm 2.8 \\
n=40\end{array}$ & $\begin{array}{c}13.4 \pm 1.3 \\
n=43\end{array}$ & $\begin{array}{c}38.9 \pm 2.2 \\
n=40\end{array}$ & $\begin{array}{c}3.5 \pm 0.1 \\
n=46\end{array}$ \\
\hline & Diverted & $\begin{array}{c}48.3 \pm 2.5 \\
n=65\end{array}$ & $\begin{array}{l}6.7 \pm 0.6 \\
n=74\end{array}$ & $\begin{array}{c}39.2 \pm 2.2 \\
n=65\end{array}$ & $\begin{array}{c}2.8 \pm 0.1 \\
n=74\end{array}$ \\
\hline \multicolumn{2}{|c|}{$\begin{array}{l}\text { Statistical significance } \\
\text { of diversion effects }\end{array}$} & NS & $p<0.001$ & NS & $p<0.001$ \\
\hline \multirow{2}{*}{ Fed } & Returned & $\begin{array}{c}54.6 \pm 4.6 \\
n=28\end{array}$ & $\begin{array}{l}4.1 \pm 0.6 \\
n=35\end{array}$ & $\begin{array}{c}48.2 \pm 4.6 \\
n=28\end{array}$ & $\begin{array}{c}2.9 \pm 0.1 \\
n=36\end{array}$ \\
\hline & Diverted & $\begin{array}{c}54.2 \pm 3.1 \\
n=41\end{array}$ & $\begin{array}{l}3.8 \pm 0.3 \\
n=49\end{array}$ & $\begin{array}{c}48.0 \pm 3.2 \\
n=41\end{array}$ & $\begin{array}{c}2.4 \pm 0.1 \\
n=49\end{array}$ \\
\hline \multicolumn{2}{|c|}{$\begin{array}{l}\text { Statistical significance } \\
\text { of diversion effects }\end{array}$} & NS & NS & NS & $p<0.01$ \\
\hline
\end{tabular}

Five pancreatic duct fistulated pigs

\begin{tabular}{|c|c|c|c|c|c|}
\hline $\begin{array}{l}\text { Feeding } \\
\text { conditions }\end{array}$ & $\begin{array}{l}\text { Pancreatic } \\
\text { secretion }\end{array}$ & $\begin{array}{l}\text { Whole } \\
\text { M.M.C. }\end{array}$ & $\begin{array}{c}\text { I } \\
\text { Quiescence }\end{array}$ & $\stackrel{11}{I . S . A .}$ & $\begin{array}{l}\text { III } \\
\text { R.S.A. }\end{array}$ \\
\hline \multirow{2}{*}{ Fasted } & Returned & $\begin{array}{c}73.4 \pm 3.9 \\
n=44\end{array}$ & $\begin{array}{c}18.2 \pm 1.4 \\
n=62\end{array}$ & $\begin{array}{c}52.5 \pm 3.5 \\
n=44\end{array}$ & $\begin{array}{c}3.2 \pm 0.1 \\
n=62\end{array}$ \\
\hline & Diverted & $\begin{array}{c}65.7 \pm 3.4 \\
n=61\end{array}$ & $\begin{array}{c}11.2 \pm 0.9 \\
n=82\end{array}$ & $\begin{array}{c}51.8 \pm 3.2 \\
n=61\end{array}$ & $\begin{array}{c}3.0 \pm 0.1 \\
\mathrm{n}=83\end{array}$ \\
\hline \multicolumn{2}{|c|}{$\begin{array}{l}\text { Statistical significance } \\
\text { of diversion effects }\end{array}$} & NS & $p<0.001$ & NS & $\mathrm{p}<0.05$ \\
\hline \multirow{2}{*}{ Fed } & Returned & $\begin{array}{c}53.9 \pm 2.3 \\
n=60\end{array}$ & $\begin{array}{l}5.4 \pm 0.5 \\
n=71\end{array}$ & $\begin{array}{c}46.0 \pm 2.3 \\
n=60\end{array}$ & $\begin{array}{c}2.9 \pm 0.1 \\
\mathrm{n}=72\end{array}$ \\
\hline & Diverted & $\begin{array}{c}55.8 \pm 2.2 \\
n=50\end{array}$ & $\begin{array}{c}4.5 \pm 2.2 \\
n=59\end{array}$ & $\begin{array}{c}48.8 \pm 2.2 \\
n=50\end{array}$ & $\begin{array}{c}3.0 \pm 0.1 \\
n=59\end{array}$ \\
\hline \multicolumn{2}{|c|}{$\begin{array}{l}\text { Statistical significance } \\
\text { of diversion effects }\end{array}$} & NS & NS & NS & NS \\
\hline
\end{tabular}

I.S.A.: Irregular spiking activity; R.S.A.: Regular spiking activity; N.S.: Not significant ; $\mathrm{n}=$ number of data. 

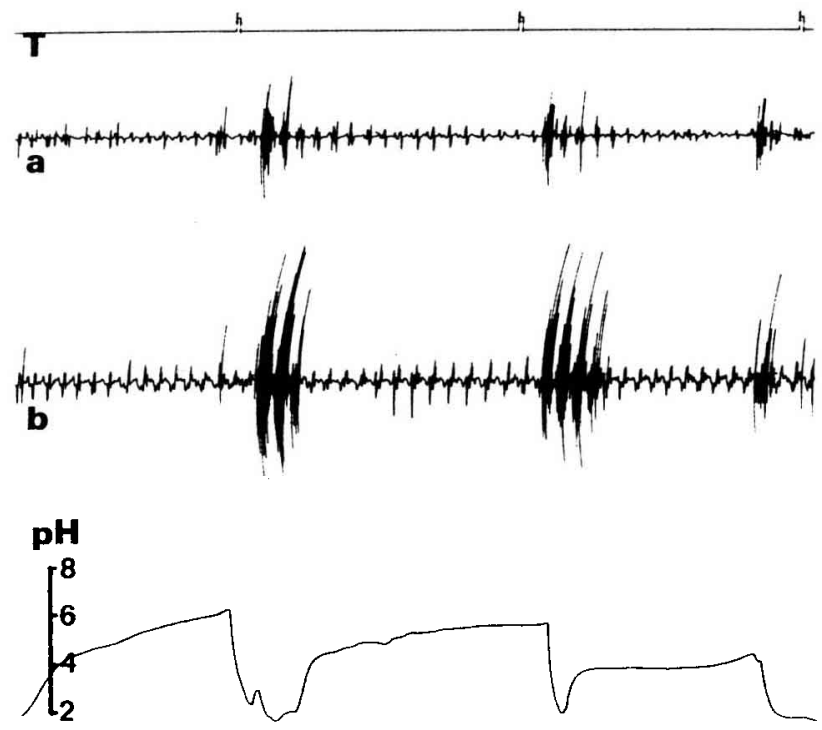

FIG. 4. - Coincidence between intraduodenal pH fluctuations and irregular myoelectric spiking activities $(\mathrm{a}, \mathrm{b})$ in the proximal duodenum after emptying of an acid bolus by the stomach. $T=$ time basis, $1 \mathrm{~min}$.



FIG. 5. - Cyclical variation of intraduodenal $\mathrm{pH}$ associated with the MMC pattern recorded from the proximal duodenum (4 locations: a, b, c, d).

1 : End of ISA followed by a RSA phase during which the $\mathrm{pH}$ reached a plateau.

2: Quiescent phase during which the $\mathrm{pH}$ plateau continued unmodified. The period illustrated here lasted $8 \mathrm{~min}$.

3: End of quiescent phase and beginning of ISA phase. An abrupt fall of $\mathrm{pH}$ occurred in connection with the first gastric emission during early ISA phase. 
fed conditions when the secretions were being returned to the duodenum. The maximum mean $\mathrm{pH}$ variation during the cycle ranged from 1.29 (pancreas series) to 1.43 (bile series) $\mathrm{pH}$ units in fasted animals, and from 1.53 (pancreas series) to 1.76 (bile series) $\mathrm{pH}$ units in fed animals. There was a greater variation in amplitude in the fed pigs. In addition, the mean $\mathrm{pH}$ values recorded during each phase were systematically a little more acid in fed than in fasted animals. This difference ranged from 0.5 to $0.7 \mathrm{pH}$ units in phases I and III and reached 0.9 to 1.2 during the ISA period (IIa and IIb).
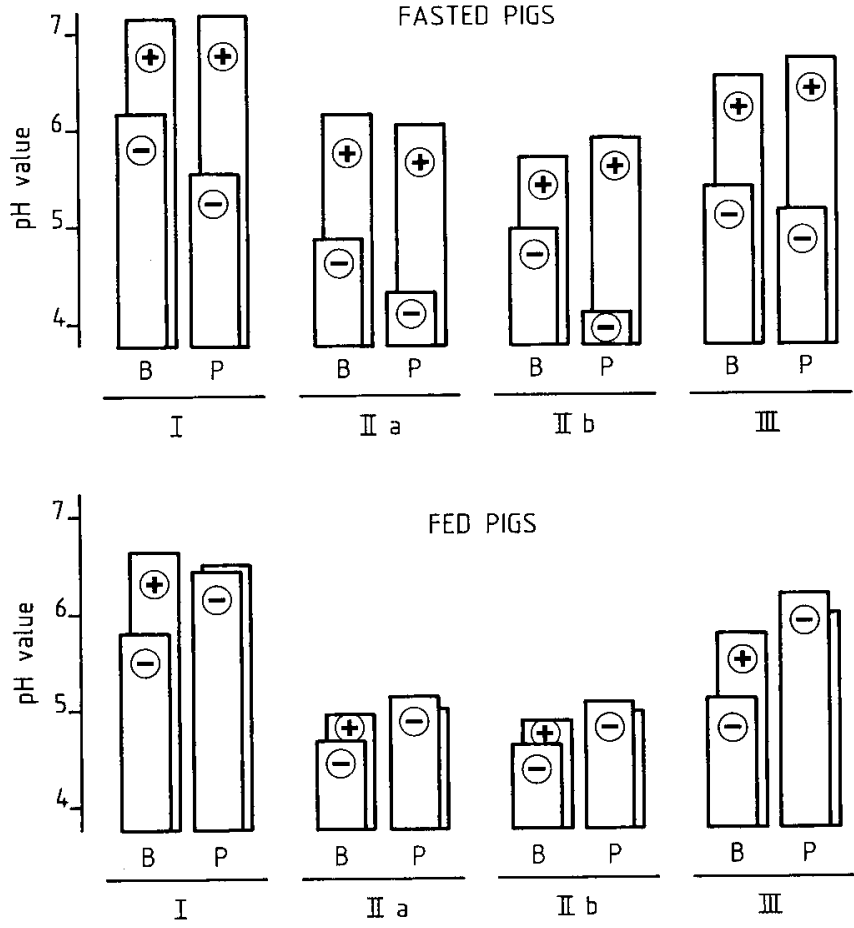

FIG. 6. - Intraduodenal $\mathrm{pH}$ mean values during the different consecutive MMC phases : quiescent phase (I), ISA phase (Ila and IIb), RSA phase (III) in fasted or fed pigs fitted with a biliary (B) or pancreatic ( $\mathrm{P})$ fistula for restitution (+) or total extracorporal diversion $(-)$ of the involved secretion. Diversion of secretion $(-v s+)$ caused a significant $(\mathrm{P}<0.001)$ fall in $\mathrm{pH}$ except in the case of pancreatic secretion in fed pigs.

The cyclical variation of duodenal $\mathrm{pH}$ was still observed when bile or pancreatic secretion was diverted from the duodenum (fig. 6). In fasted conditions, the maximum variation of the mean $\mathrm{pH}$ value ranged from 1.31 (bile diversion) to 1.45 units (pancreatic diversion). In fed conditions, the maximum cyclical variation ranged from 1.18 (bile diversion) to 1.36 units (pancreatic diversion). This pattern of variation was analogous (fasted animals) or not 
significantly different (fed pigs) when compared with values obtained in animals whose secretions were returned to the duodenum. The $\mathrm{pH}$ range within which the cyclical variation took place was very significantly $(p<0.001)$ more acid during bile or pancreatic juice diversion in fasted pigs and during bile diversion in fed animals. The diversion of pancreatic secretion did not affect the mean intraduodenal $\mathrm{pH}$ values in any phase of the $\mathrm{MMC}$ in fed pigs. During the postprandial motor pattern, the intraduodenal $\mathrm{pH}$ was on an average significantly $(\mathrm{p}<0.001)$ more acid under diversion of bile or pancreatic secretion (5.07 and 5.27, respectively) than during the restitution of these secretions (5.44 and 5.45).

\section{Discussion.}

This study in the pig proves that the flow rate of biliary and pancreatic secretions varies rhythmically in relation to duodenal MMC. We confirm that the pig exhibits a cyclical variation of intraduodenal $\mathrm{pH}$ occurring concomitantly with the duodenal MMC cycle. The systematic analysis of the effects of biliary or pancreatic diversion allows us to speculate on the contribution of gastric, biliary and pancreatic secretions to this fluctuation.

However, to assess the physiological connections between intestinal motility, secretions and $\mathrm{pH}$ it is necessary to determine whether the techniques used alter duodenal myoelectric activity and whether the MMC is disturbed by the diversion of biliary or pancreatic secretions. During the restitution of biliary or pancreatic secretions according to a procedure already validated (Juste, Corring and Le Coz, 1983a), neither fistulation of the common bile duct or of the pancreatic duct, nor the presence of a duodenal T-shaped cannula led to disturbances of the MMC. The mean values of the MMC cycle period were found to be similar to those previously described $(60-70 \mathrm{~min}$ ) in intact pigs (Laplace, 1978). Likewise, the mean length of the postprandial pattern in the two series of pigs corresponded to usual values taking into account the size of the meals (Ruckebusch and Buéno, 1976 ; Laplace, 1978). The permanent diversion of secretions caused no large changes, and the MMC cycle period was not affected in fasted or fed pigs. This is in keeping with the fact that a variation in the amount of bile acids poured into the duodenum did not affect the cycle period of the MMC in dogs (Scott, 1986). However the opposite has been reported by Romanski et al. (1986) who described the disappearance of duodenal RSA during bile acid depletion in dogs, and the restoration of the cycling pattern by infusion of individual bile acids.

The gastrointestinal secretions, together with the buffering ability of the food, contribute to intraluminal $\mathrm{pH}$. According to the design of our study, diversion of either biliary or pancreatic secretion using well-tried techniques (Corring, Aumaitre and Rérat, 1972 ; Corring, Juste and Jimenez, 1983), should not affect the secretory rate of the other or even gastric acid secretion. Indeed, neither the secretion of bile nor that of gastric acid seems to be disturbed by pancreatic 
secretion diversion. Similar to our observations in pigs, humans suffering from pancreatic insufficiency experience relative acidification of the intraduodenal medium resulting from a reduced capacity to neutralize gastric acid (Dutta, Russell and Iber, 1979a and b). However, a marked increase in gastric acid secretion has been reported in dogs after pancreatic duct ligation (Sekine et al., 1981). As regards bile duct fistulation, the secretion may either be returned into the lower common bile duct in order to irrigate the Oddi sphincter, or directly to the duodenum like in this experiment. Though the contractions of the Oddi sphincter delay the outflow of bile from the common bile duct towards the intestine (Laplace, 1976a), the latter method did not affect the postprandial secretion of bile from the gallbladder (Corring, Juste and Jimenez, 1983) or the bile volume; it did significantly reduce the 24 -h bile acid production (Juste, Corring and Le Coz, 1983b), but this had no effect on the buffering ability of the bile. Despite the bypass of the sphincter in our pigs, the intermittent bile outflow during the ISA phase (approximately 4 groups of drops per min) could give some support to the passive pumping mechanism of bile in the common duct suggested by Rayner, Wenham and Gregory (1984). But exclusion of the Oddi sphincter does not eliminate the pulsatile pattern of fasting duodenal bile acid delivery in the dog (Scott, Eidt and Shaffer, 1985). So the techniques used do not give rise to abnormalities. Nevertheless it cannot be excluded that bile diversion affects gastric and/or pancreatic secretions in pigs. For example, gastric acid hypersecretion and pancreatic inhibition were recorded in bile deprived dogs (Davies et al., 1985).

Under the above limitation, the described cyclic variations in biliary and pancreatic output proved to be a true secretory component of duodenal MMC in pigs. Due to overlapping of the plateau of alkalinization with the RSA and quiescent phases (which did not correspond to any passage of digesta) and to the coincidence of the acid phase with the ISA phase (during which the gastroduodenal transit occurred) Buéno and Fioramonti (1982) considered that only the flow of acid gastric digesta and its interruption during the RSA and quiescent phases were responsible for cyclic $\mathrm{pH}$ variations. However, in their experimental conditions, bile and pancreatic secretion were diverted together with gastric outflow. This extracorporal diversion of total duodenal contents being performed proximal to the site of $\mathrm{pH}$ measurement, the stable neutral $\mathrm{pH}$ value recorded by Buéno and Fioramonti (1982) reflected only the contribution of duodenal secretions. They therefore could not speculate on the potential contributing factors. Our experimental results demonstrate, under conditions of normal gastroduodenal transit, that neither diversion of bile nor of pancreatic secretion suppresses cyclical variation in $\mathrm{pH}$, and suggest that the flow of acid gastric digesta could play a determining role. This is in agreement with the occurrence of gastric emptying during the duodenal ISA phase and the cessation of gastric outflow at the onset of the duodenal RSA phase (Laplace, 1978). Nevertheless, the very important role of biliary and pancreatic secretions in the neutralization of duodenal chyme in the pig, previously established (Abello, Corring and Laplace, 
1987), is also demonstrated in the present study since the cyclical variation in $\mathrm{pH}$ took place within a much more acid range during biliary or pancreatic diversion in fasting pigs.

Speculating on possible mechanisms of coordination, several hypotheses can be considered, depending on whether fluctuations in secretions and $\mathrm{pH}$ are responsible for the MMC phases or the reverse. In dogs under fasting conditions, the transport of intestinal bile acids to the liver has been shown to be pulsatile rather than continuous, and determined by the MMC. Maximum hepatic secretion occurs when intraluminal bile acids reach their site of absorption (Scott et al., 1983). But, the overall time necessary for transit and entero-hepatic recycling does not fit with the timing of the various events recorded in the duodenal area. Moreover both biliary and pancreatic secretions exhibit periodic fluctuations, and it was shown they were not responsible for the cyclical variation in $\mathrm{pH}$. Nevertheless, the $\mathrm{pH}$ could be the focus of reciprocal relationships, as suggested years ago by the temporary inhibition of gastric motility by acid.infusion in the small intestine (Boldyreff, 1904). Duodenal alkaline buffer solutions or pancreatic juice in dogs stimulate motility of gastric denervated pouches and - to a lesser degree - that of transplanted gastric pouches (Brown et al., 1966). Duodenal infusion of $100 \mathrm{mM} \mathrm{HCl}$ in human beings induces a contractile activity resembling the duodenal RSA phase of a MMC (Lewis et al., 1979). The cumulative effects of acid digesta emptied from the stomach could induce the duodenal RSA phase, which in turn results in the gastric quiescent period. Then cumulative effects of alcalinity in the duodenum could re-activate gastric motility. According to such a sequence, cyclic variations of intra-duodenal $\mathrm{pH}$ and $\mathrm{MMC}$ cycles in the gastro-duodenal area would be a self-induced alternating system. However such an hypothesis does not fit, for example, with the existence of a sustained acid flow during the postprandial pattern, nor with the fact that acid-induced duodenal RSA in human beings is not preceded by a maximal gastric activity (Lewis et al., 1979).

Accordingly, it may be suggested that various nervous and/or humoral mechanisms are involved in intraduodenal acidification. Cyclical variations in the plasma levels of motilin (Cuber, Laplace and Chayvialle, 1984), cholecystokinin (Cuber et al., 1986a), gastrin and pancreatic polypeptide (Cuber et al., 1986b) with a periodicity closely related to that of the MMC were recently described in the pig. Results obtained in pigs also suggest that the acidification may lead to a growing release of various peptides such as secretin (Cuber et al., 1985). The occurrence of a $\mathrm{pH}$ close to neutrality during early $\mathrm{RSA}$ may interrupt this release and could account for the rapid decrease in biliary and pancreatic flow rates. According to this, the $\mathrm{pH}$ cycle, which appears to be a consequence of the motor cycle (gastric acid delivery), might regulate rhythmic variation in the secretion of biliary and pancreatic secretions. It may also be suggested that the internal clock of the myenteric plexus (Laplace, 1984) directly controls both the MMC (through the cholinergic neuronal network) and the release of various regulatory peptides from the duodenum, or indirectly affects the release of various peptides due to intraduodenal $\mathrm{pH}$ conditions. Thus the observed chronological relationships would only reflect a sequential control by neural and peptidergic factors. Specific 
studies would therefore be required before stating that the biliary and pancreatic secretory component of the MMC in pigs is the consequence of one or the other of the above mechanisms or of a combination of them.

Reçu en septembre 1987 Accepté en mai 1988.

Résumé. Composante sécrétoire biliaire et pancréatique des complexes myoélectriques migrants chez le Porc. Incidence sur le pH intraduodénal.

L'objectif de cette étude chez le porc est double: (1) mettre en évidence l'existence d'une composante sécrétoire biliaire et pancréatique des complexes myoélectriques (CMM) en période interdigestive et (2) examiner l'effet d'une privation totale de l'une ou l'autre de ces sécrétions sur la structure des CMM et la variation cyclique du $\mathrm{pH}$ intraduodénal.

Six porcs $(50,6 \pm 1,6 \mathrm{~kg})$ ont été munis d'un cathéter permanent soit dans le canal cholédoque ( 3 porcs), soit dans le canal pancréatique ( 3 porcs). L'ensemble des animaux a été équipé avec un cathéter duodénal pour la réintroduction de la sécrétion dérivée et d'électrodes chroniques souples implantées dans l'antre gastrique et le duodénum. Le débit de la sécrétion dérivée est enregistré parallèlement à l'activité électromyographique avant restitution. Dix porcs $(50,8 \pm 1,5 \mathrm{~kg})$ préparés de la même façon (5 porcs avec cathétérisme du canal cholédoque, 5 porcs avec cathétérisme du canal pancréatique) ont en outre été munis d'une canule duodénale en $T$ positionnée à $19 \mathrm{~cm}$ du pylore et permettant l'introduction d'une électrode pour la mesure du $\mathrm{pH}$. Ce dernier a été enregistré parallèlement à l'activité électromyographique dans 4 situations différentes : sécrétions réintroduites, en période interdigestive ou postprandiale; bile ou suc pancréatique non réintroduit, chez le porc alimenté ou à jeun.

Les débits de bile et de suc pancréatique sont très importants pendant le déroulement de l'activité irrégulière $(\mathrm{Al})$, avec un maximum à la fin de celle-ci juste avant le déclenchement de l'activité régulière $(A R)$, et à l'inverse très faibles pendant la phase de quiescence. La durée des CMM duodénaux et de leurs phases constitutives n'est pas fondamentalement modifiée par une dérivation extracorporelle totale de la bile ou du suc pancréatique, que ce soit en période interdigestive ou postprandiale. En période interdigestive, le $\mathrm{pH}$ est significativement diminué lors de dérivation de la bile (quiescence : 6,17 vs 7,15 ; Al : 4,91 vs 5,94 ; AR : 5,40 vs 6,52 ) ou du suc pancréatique (quiescence : 5,56 vs 7,18; Al : 4,21 vs 5,97; AR : 5,14 vs 6,72). En période postprandiale, seule la dérivation de la bile entraîne une acidification pendant les déroulements du " pattern " postprandial $(5,07$ vs 5,44$)$, des phases de quiescence $(5,81$ vs 6,61$)$, d'Al $(4,66$ vs 4,92$)$ et d'AR $(5,11$ vs 5,78 ). Néanmoins la périodicité des fluctuations du $\mathrm{pH}$ liée au déroulement du cycle des CMM subsiste lors de dérivation de bile ou de suc pancréatique.

Ces résultats mettent en évidence l'existence chez le porc d'une composante sécrétoire biliaire et pancréatique des CMM duodénaux, et confirment que ces sécrétions ont un rôle important dans la neutralisation des contenus duodénaux. Néanmoins la variation cyclique du $\mathrm{pH}$ intraduodénal s'avère essentiellement déterminée par la périodicité du débit des digesta gastriques acides.

\section{Références}

ABELLO J., CORRING T., LAPLACE J. P., 1987. Contribution of bile and pancreatic juice to the control of $\mathrm{pH}$ in the pig duodenum. Reprod. Nutr. Dévelop., 27, 681-687.

BOLDYREFF W. N., 1904. Thesis, St. Petersburg. Quoted by BABKIN (1928). Die aussere Sekretion der Verdauungsdrüsen. Ed. 2 J. Springer, Berlin. 
BROWN J. C., JOHNSON L. P., MAGEE D. F., 1966. Effect of duodenal alkalinization on gastric motility. Gastroenterologv, 50, 333-339.

BUÉNO L., FIORAMONTI J., 1982. Origin of the cyclical variations of the duodenal pH in pig, 169-173. In WIENBECK M., Motility of the digestive tract, Raven Press, New York.

CODE C. F., MARLETT J. A., 1975. The interdigestive myoelectric complex of the stomach and small bowel of dogs : J. Physiol. (London), 246, 289-309.

CORRING T., AUMAITRE A., RERAT A., 1972. Fistulation permanente du pancréas exocrine chez le Porc. Application : Réponse de la sécrétion pancréatique au repas. Ann. Biol. anim. Bioch. Biophys., 12, 109-124.

CORRING T., JUSTE C., JIMENEZ R., 1983. Fistulation du cholédoque chez le Porc. Sci. Tech. Anim. Lab., 8, 227-236.

CUBER J. C., BERNARD C., LAPLACE J. P., CHAYVIALLE J. A., 1985. Comparative assessment of secretin and motilin responses to graded duodenal acidification in anaesthetised pigs. Digestion, 32, 35-41.

CUBER J. C., BERNARD C., LAPLACE J. P., LeVENEZ F., ChAYVIALle J. A., 1986a. Plasma cholecystokinin like immunoreactivity varies cyclically during the migrating myoelectric complexes in the pig. Can. J. Physiol. Pharmacol., 64, 45 (abstr.).

CUBER J. C., LAPLACE J. P., CHAYVIALLE J. A., 1984. Motilin and myoelectric complexes, 231 -237. In ROMAN C., Gastrointestinal motility, MTP Press Ltd, Lancaster.

CUBER J. C., LAREDO C., LAPLACE J. P., CHAYVIALLE J. A., 1986b. Autocovariance analysis of plasma motilin, pancreatic polypeptide, somatostatin and gastrin levels during the migrating myoelectric complex (MMC) sequence in the conscious pig. 3rd Europ. Symo. Gastrointestinal motility, Bruges (abstr. 32)

DAVIES H. A., WHEELER M. H., PSAILA J., RHODES J., NEWCOMBE R. G., JONES J. M., PROCTER D., ADRIAN T. E., BLOOM S. R., 1985. Bile exclusion from the duodenum. Its effect on gastric and pancreatic function in the dog. Dig. Dis. Sci, 30, 954-960.

DIMAGNO E. P., HENDRICKS J. C., GO V. L. W., DOZOIS R. R., 1979. Relationships among canine fasting pancreatic and biliary secretions, pancreatic duct pressure, and duodenal phase III motor activity. Boldyreff revisited. Dig. Dis. Sci, 24, 689-693.

DUTTA S. K., RUSSELL R. M., IBER F. L., 1979a. Influence of exocrine pancreatic insufficiency on the intraluminal $\mathrm{pH}$ of the proximal small intestine. Dig. Dis. Sci., 24, 529-534.

DUTTA S. K., RUSSELL R. M., IBER F. L., 1979b. Impaired acid neutralization in the duodenum in pancreatic insufficiency. Dig. Dis. Sci, 24, 775-780.

JUSTE C., CORRING T., LE COZ Y., 1983a. Bile restitution procedures for studying bile secretion in fistulated pigs. Lab. Anim. Sci, 33, 199-202.

JUSTE C., CORRING T., LE COZ Y., 1983b. Bile secretion in the fistulated pig : effect of the method used for bile reinfusion. Reprod. Nutr. Dévelop., 23, 765-773.

KEANE F. B., DIMAGNO E. P., DOZOIS R. R., GO V. L. W., 1980. Relationships among canine interdigestive exocrine pancreatic and biliary flow, duodenal motor activity, plasma pancreatic polypeptide, and motilin. Gastroenterology, 78, 310-316.

LAPLACE J. P., 1972. Motricité gastro-intestinale chez le Porc : étude descriptive par électromyographie et corrélations nutritionnelles. Rec. Méd. vét., 148, 37-61.

LAPLACE J. P., 1976a. L'excrétion biliaire chez le Porc ; 1) Electromyographie des voies biliaires extra-hépatiques. Rec. Méd. vét., 152, 33-43.

LAPLACE J. P., 1976b. L'excrétion biliaire chez le Porc; 2) Electromyographie et dynamique de l'excrétion de bile. Rec. Méd. vét., 152, 401-411.

LAPLACE J. P., 1978. Organisation de la motricité de l'intestin grêle chez le porc et influence de l'alimentation. Ann. Zootech., 27, 377-408.

LAPLACE J. P., 1983. Electromyographie gastro-intestinale chronique chez le Porc. Sci. Tech. Anim. Lab., 8, 251-259.

LAPLACE J. P., 1984. Intestinal motility. A review of myoelectric and motor migrating complexes, 1-20. In BATT R. M., LAWRENCE T. L. J., Function and dysfunction of the small intestine, Liverpool University Press Ed.

LEWIS T. D., COLLINS S. M., FOX J.-A. E., DANIEL E. E., 1979. Initiation of duodenal acid-induced motor complexes. Gastroenterology, 77, 1217-1224

LUX G., LEDERER P., FEMPPEL J., SCHMACK B., ROSCH W., DOMSCHKE W., 1980. Motor and secretory activity of the duodenal interdigestive complex : an integrated function, 311-318. in CHRISTENSEN J., Gastrointestinal motility, Raven Press, New York. 
PEETERS T. L., VANTRAPPEN G., JANSSENS J., 1980. Bile acid output and the interdigestive migrating motor complex in normals and in cholecystectomy patients. Gastroenterology, 79, 678-681.

RAYNER V., WENHAM G., GREGORY P. C., 1984. Stomach motility modulates bile flow in the pig, 205-211. In ROMAN C., Gastrointestinal motility, MTP Press Ltd, Lancaster.

ROMANSKI K. W., PEETERS T. L., JANSSENS J., VANTRAPPEN G., 1986. The effect of individual bile acids on interdigestive motility. 3rd Europ. Symp. Gastrointestinal motility, Bruges (abstr. 39).

RUCKEBUSCH Y., BUENO L., 1976. The effect of feeding on the motility of the stomach and small intestine in the pig. Br. J. Nutr., 35, 397-405.

SCOTT R. B., 1986. Effect of duodenal bile acid delivery on fasting intestinal motor activity. Am. $J$. Physiol., 250, G 836-G 841 .

SCOTT R. B., EIDT P. B., SHAFFER E. A., 1985. Regulation of fasting canine duodenal bile acid delivery by sphincter of Oddi and gallbladder. Am. J. Physiol., 249, G 622-G 633.

SCOTT R. B., STRASBERG S. M., EL-SHARKAWY T. Y., DIAMANT N. E., 1983. Regulation of the fasting enterohepatic circulation of bile acids by the migrating myoelectric complex in dogs. J. clin. Invest., 71, 644-654.

SEKINE T., KAMEYAMA J., SASAKI I., LIN J., SATO T., 1981. Influence of pancreatic duct ligation on gastric acid secretion. Tohoku J. exp. Med., 134, 29-38.

SZURSZEWSKI J. H., 1969. A migrating electric complex of the canine small intestine. Am. J. Physiol., 217, 1757-1763.

VANTRAPPEN G. R., PEETERS T. L., JANSSENS J., 1979. The secretory component of the interdigestive migrating motor complex in man. Scand. J. Gastroent., 14, 663-667.

WINGATE D. L., 1981. Backwards and forewards with the migrating complex. Dig. Dis. Sci., 26, $641-666$. 